\title{
$\operatorname{SiC}$ 繊維を混合した Al 粉末合金の製造とその摩擦特性
}

\section{The fabrication and the friction characteristic of an aluminum powder alloy which mixed the SiC fiber}

\author{
正 林 伸和（豊田高専） 正 小林 政教（豊田高専） \\ ○学 畠中 辰哉（豐田高専専攻科）
}

Nobukazu Hayashi, Toyota National College of Technology, Eisei-cho 2-1, Toyota-shi, Aichi Masanori Kobayashi, Toyota National College of Technology

Tatsuya Hatanaka, Toyota National College of Technology, Advanced Engineering Course

\section{1。緒言}

環境への負荷が問題とされている近年，潤滑油を使わない 新しい摩擦機構への関心が高まっている。そこで本研究では 強度, 耐摩耗性の優れる Si を $20 \%$ 含む $\mathrm{Al}$ 合金を粉末法によ り製造し，その摩擦特性を検討した。この粉末合金に $\mathrm{SiC}$ 粒 子を混合し特性が向上したという報告があるため，ここでは 混合材の有無さらに粒子形状の影響を見るため， $\mathrm{SiC}$ 㵶維を 混合した場合を検討した。

\section{2。 $\mathrm{SiC}$ 紷維}

今回本研究に用いた繊維は炭化ケイ素系繊維で，元素成分 は Si: $50 \%, \mathrm{C}: 30 \%, 0: 18 \%$, Ti:2\%であるが，ここでは SiC 繊維と呼ぶことにする。初期形状は, 直径 $13 \mu \mathrm{m}$, 㵶維長 $6 \mathrm{~mm}$, 引張強度は $3000 \mathrm{M} \mathrm{Pa}$ である。A l 粉末と混合するとき $\mathrm{SiC}$ 繊維は ‘だま’（固まり）になり易いため，ミキサーで繊維を

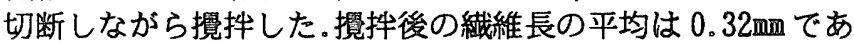

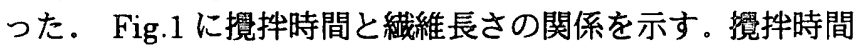
10s では‘だま’（固まり）になっているところが多くみられ 摫汼が十分ではなかった。䚌汼時間 $15 \mathrm{~s}, 30 \mathrm{~s}$ では繊維の長さ にそれほどの差がないため，本研究では掜汼時間を $30 \mathrm{~s}$ とし た。繊維径が $13 \mu \mathrm{m}$ であることから長さと繊維径の比が約 25 倍と計算でき，なお十分な長さを持った緘維であるというこ とが言える。

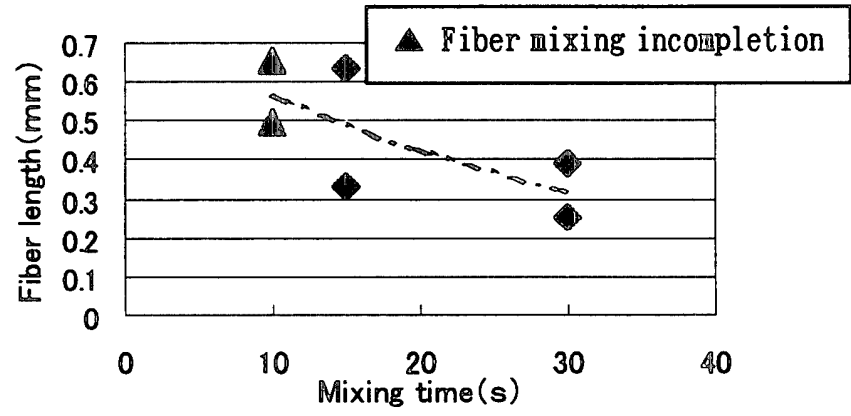

Fig.1 Fiber mixing conditions

\section{3。実験装置}

\section{1 押出し装置}

コンテナ内径は $30 \mathrm{~mm}$ ，パンチ先穴径は $5 \mathrm{~mm}$ （押出し比 36 ） の寸法の熱間後方粉末押出しを行い，棒材を製作した。

\section{2 摩擦試験機}

Fig. 2 に摩擦試験方法を示す。作製した押出し材先端を機 械加工により球面に仕上げ摩擦ピンを作る。これをスプリン グの縮みにより一定の力 $N て ゙$ 摩擦する相手の板材（摩擦板） に押しつける。その状態で板材に作用する荷重 $F$ を測定しな がら移動させることにより摩擦試験を行う。このとき摩擦係 数

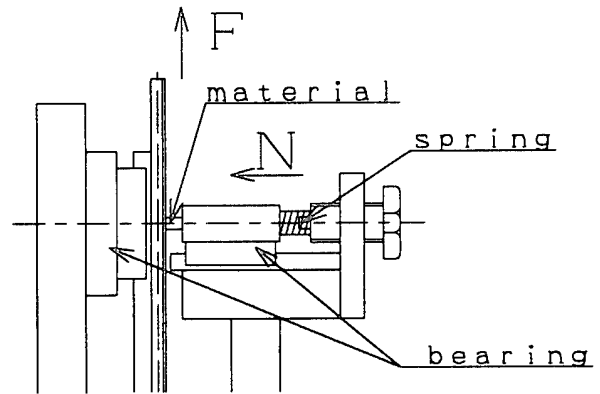

Fig.2 Method of friction test

\section{4。実瑍方法}

4.1 押出し材の製造

$\mathrm{Si}$ を $20 \mathrm{mass} \%$ 含有した平均粒子径 $0.1 \mathrm{~mm}$ の Al 粉末に $\mathrm{SiC}$ 繊維を重量比 $2 \%$ （体積比約 $2 \%$ ）の割合で混合し，ミキサ 一で 30 秒間擋挥した後コンテナに詰める.冷間で予備圧縮 をした後，773K まで加熱し，脱ガスのため 1 時間加熱保持 した後，熱間押出しにより直径 $\varnothing 5$ m m の棒材を作製した。

同様の方法で Al 粉末のみで棒材を作製した。Fig.3に押 出し材製造の流れを示す。

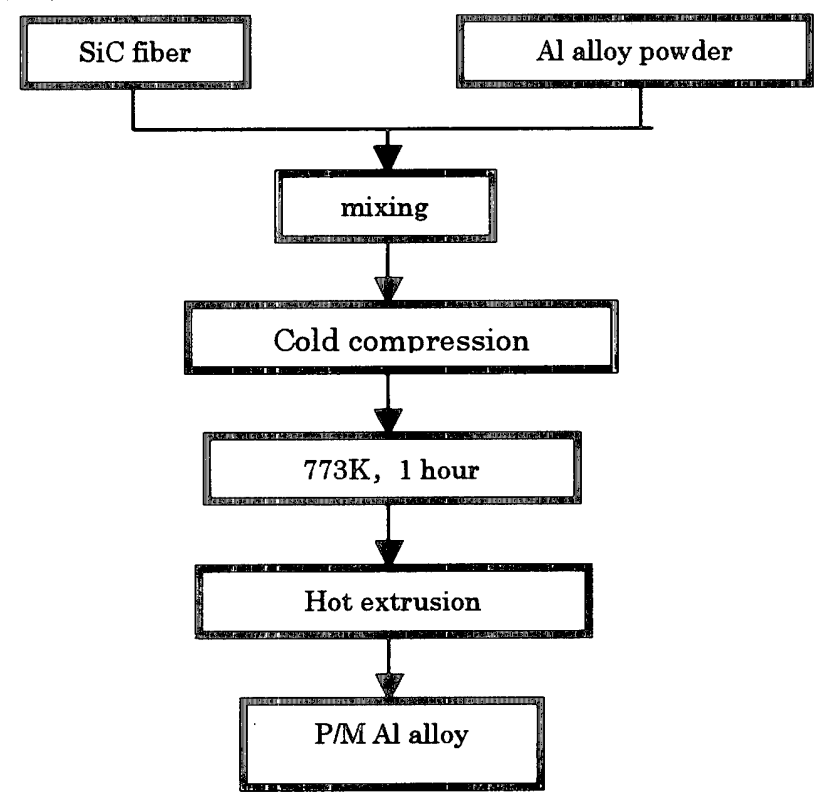

Fig.3 Process for making $\mathrm{Al}$ alloy

\section{2 摩擦試験}

各棒材の先端を半径 $26 \mathrm{~mm}$ の球面に加工し摩擦ピンとし た。表面仕上げは苂1000 の耐水ペーパー研磨とした。それ ぞれの摩擦ピンに対し,板厚 0.6mm の工業用純 A 1 A 1050 H24 材を相手材とし，圧縮力 $9.8 \sim 92.7 \mathrm{~N}$, 速度 $1 \mathrm{~mm} / \mathrm{sec}$ で，ストローク 150洫まで無潤滑の摩擦試験を行った。

日本機械学会東海支部第53期総会講演会講演論文集（'04.3. 17-18）No. 043-1 


\section{5. 実験結果およひ考察}

\section{1 摩擦試験結果}

Fig.4に製作した $\mathrm{SiC}$ 㵶維混合押出材の断面写真を示す.

Fig.5, Fig.6 に摩擦ピン荷重 $19.6 \mathrm{~N}, 92.7 \mathrm{~N}$ の場合のA 1 粉末のみと S i C 繊維混合 A I 粉末押出し材の摩擦試験結果 を示す. Fig.7 は種々の摩擦ピン荷重における A 1 粉末のみ と S i C 繊維混合 A 1 粉末押出し材の摩擦係数を示す.なお, Fig.7 の摩擦係数值は，いずれの場合も摩擦力の変動が小さ く,ほぼ定值となるストロークが $100 \sim 150 \mathrm{~mm}$ 付近の值で ある・

$\mathrm{SiC}$ 繊維は均一に分布し，かつ繊維の向きが，棒材の長手 方向に一様にそろっていた。

本研究では, 棒状の押出し材を摩擦材として用いるが, Fig.4 から摩擦面がある程度の摩耗が進んでも， $\mathrm{SiC}$ が抜け 落ちることなく, 安定した摩擦材料となっていることが期待 できる。

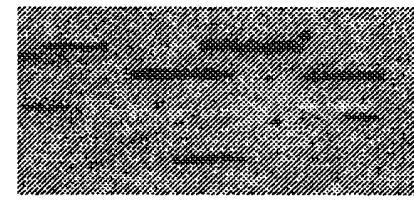

(a) Longitudinal

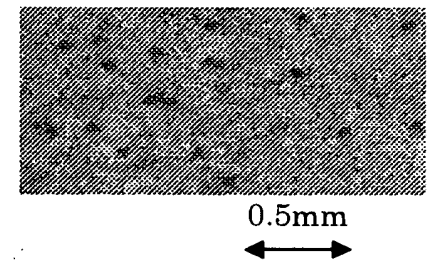

(b) Transverse
Fig.4 Photographs of cross section

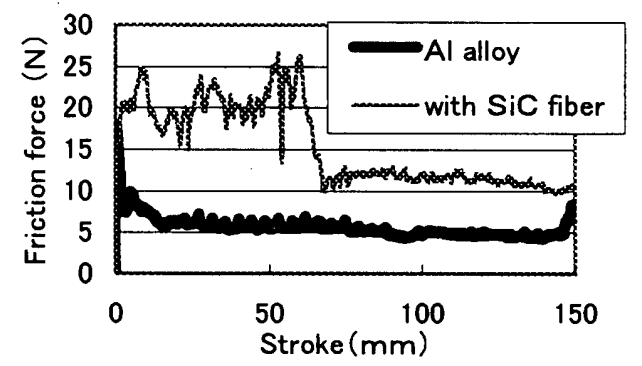

Fig.5 Change of friction force in $N=19.6 \mathrm{~N}$

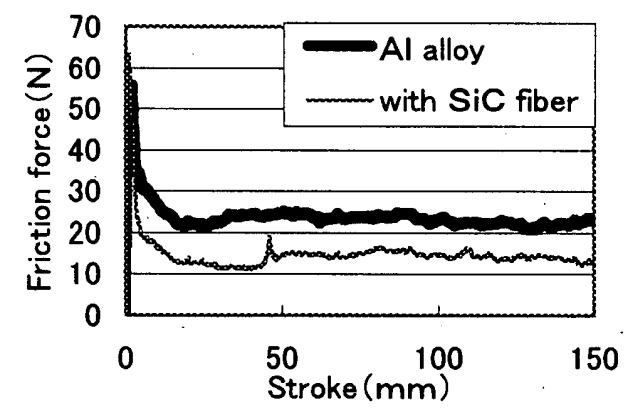

Fig.6 Change of friction force in $N=92.7 \mathrm{~N}$

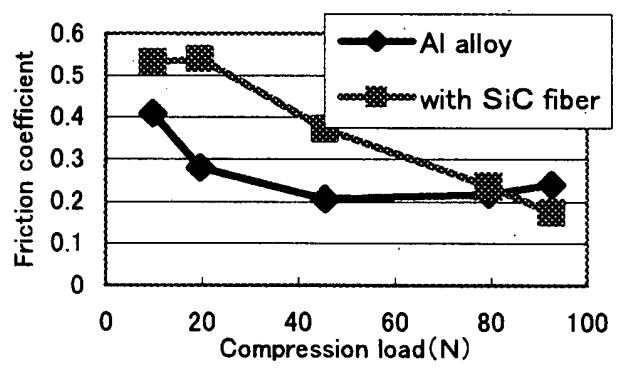

Fig.7 Relation between friction coeffcient and compression load
摩擦ピン荷重が 19.6N(Fig.5)のとき S i C 繊維混合 A 1 粉末押出し材ははじめ焼きつきを起こすが, ストロークが 50 $\mathrm{mm}$ 方よひ $60 \mathrm{~mm}$ を越えると, 摩擦力は低く一定值に安定し た.荷重が増加し，92.7N(Fig.6)では工程の初期から焼きつ きが発生しないことが注目される。

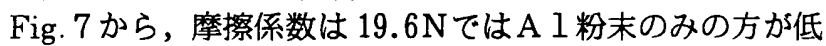
い值を示していたが, 92.7NではS i C 瀻維混合 A 1 粉末押 出し材の方が低い值を示したことが非常に興味深い特幑とい うことができる。

\section{2 摩擦面観察}

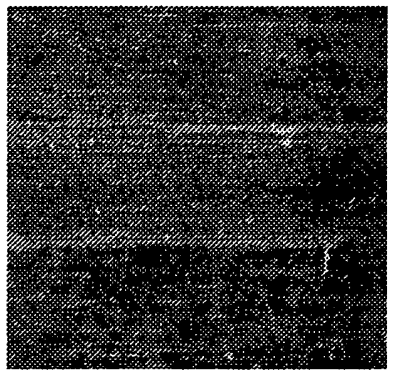

(a) No adhesion

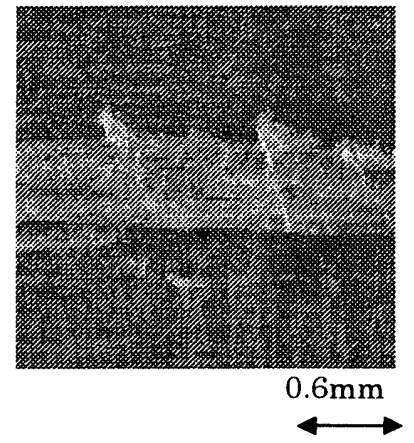

(b) Adhesion
Fig.8 Photographs of the surface

Fig.8(a)は，92.7Nの摩擦痕写真である. 焼きつきを起こし ていないところでは(a)のように板材に残った摩擦痕は板材 がへこんだ様な状態になっている。

Fig.8(b) は, 19.6Nのグラフ中の焼きつきを起こしている ストローク $50 \mathrm{~mm}$ 付近の摩擦痕の状態を示している.ここでは, 板材は摩擦ピンにえぐられた様な状態になっている.ただし， $19.6 \mathrm{~N}$ のストローク $100 \mathrm{~mm}$ 付近の摩擦痕の状態は, Fig.8(a) より摩擦幅は狭くなるが同様にへこんだ様な痕が残っていた。

このように，焼きつき発生の有無は摩擦面観察にようて区 別できるが, 焼きつかないときのわずかの摩擦係数の違いと 表面性状の関係については, 今後の課題としたい.

\section{6. 結言}

押出し材を製造するプロセスにおいて,以下の結論を得た.

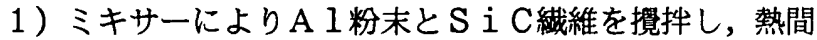
後方押出しをすることにより繊維が均一に分散した押出 し材を得ることができた。

2）S i C 繊維の向きは押出し方向に並んでに整列した。

摩擦ピンとしてA 1 押出し材，S i C 䄉維混合 A I 粉末押 出し材を用いたとき, A 1050一H24 板を相手材として摩擦試 験をしたところ，以下の結論を得た。

1) S i C 繊維混合A 1 粉末押出し材は, 無潤滑の場合は 摩擦ピン荷重 19.6Nではストローク 50〜 60mmまで 周期的に焼きつきを起こすが，92.7Nでは焼きつきを 起こさない。

2) 板材に残った摩擦痕の状態は, 焼きつきを起こしてい ない場所では板材にへこんだような跡が残り，焼きつ きを起こしている場所では板材は摩擦ピンにえぐられ たような痕か残る。

3 ) 摩擦係数は摩擦ピン荷重が $19.6 \mathrm{~N}$ では, A 1 粉末押出 し材の方が S i C 繊維混合 A I 粉末押出し材より低い 值を示したが，92.7Nで S i C 繊維湿合 A I 粉末押出 し材の方が低い值を示し，新たな摩擦材料としての可 能性を示すことができた。 